\title{
PENGEMBANGAN WEB SEMANTIK SILSILAH KELUARGA KAWITAN NARARYA DALEM BENCULUK TEGEH KORI DENGAN METODE FORWARD CHAINING DAN BACKWARD CHAINING
}

\author{
I Made Ditha Herdia Wiranata ${ }^{1}$, I Made Putrama ${ }^{2}$, I Made Agus Wirawan ${ }^{3}$ \\ $1,2,3$ \\ Jurusan Pendidikan Teknik Informatika, Fakultas Teknik dan Kejuruan \\ Universitas Pendidikan Ganesha \\ Singaraja, Indonesia \\ e-mail: dithahw13@gmail.com¹, made.utrama@undiksha.ac.id ${ }^{2}$ \\ imade.aguswirawan@gmail.com³
}

\begin{abstract}
Abstrak
Silsilah kawitan dibentuk dengan tujuan untuk mempererat hubungan keluarga dengan tetap berada pada garis keturunannya. Namun pada dasarnya masih banyak masyarakat hindu yang tidak tahu dengan kawitanya. Hal ini karena kurangnya babad yang memuat dengan jelas terkait dengan silsilah kawitan maupun informasi yang lengkap. Dengan pengembangan Web Semantik Silsilah Keluarga Kawitan Nararya Dalem Benculuk Tegeh Kori dengan Metode Pencarian Forward Chaining dan Backward Chaining dapat mengatasi permasalahan terkait silsilah kawitan. Dengan menggunakan web ini, masyarakat akan dapat menemukan informasi yang berkaitan dengan silsilahnya dengan mudah, sehingga tidak ada lagi masyarakat yang bingung dengan kawitannya. Web ini dikembangan dengan menggunakan metode waterfall. Metode waterfall menggambarkan pendekatan sistematis dan juga berurutan dalam pengembangan perangkat lunak. Mulai dari perencanaan, pemodelan, implementasi, pengujian, sampai pemeliharaan perangkat lunak. Pengujian dilakukan kepada keluarga kawitan Nararya Dalem Benculuk Tegeh Kori. Hasil pengujian bahwa sistem informasi berbasis web bisa diterima di masyarakat dengan sangat baik.
\end{abstract}

Kata kunci: Silsilah, Web Semantik, Kawitan, AryaTegeh Kori, Forward Chaining

\begin{abstract}
The genealogy kawitan formed with the aim to strengthen family relationships by remaining in lineage. But basically there are still many Hindus who do not know their kawitan. This is because the lack of a chronicle that contains clearly related to the kawitan genealogy as well as complete information. By developing Semantic Web of the family tree of Kawitan Nararya Dalem Benculuk Tegeh Kori used a Forward Chaining and Backward Chaining Search Methods can solve the problems related to geneology kawitan. By using this web, the community will be able to find information related to its genealogy easily, so no more people are confused with their kawitan. This web is developed by using the waterfall method. Waterfall method describes a systematic approach and also sequentially on software development. Starting from the planning, modeling, implementation, testing, until the software maintenance. The tests were conducted to the family of Nararya Dalem Benculuk Tegeh Kori. The result of the test showed that the system is received in the community very well.
\end{abstract}

Keywords : Genealogy, Semantics Web, Kawitan, AryaTegeh Kori, Forward Chaining 


\section{PENDAHULUAN}

Bali memiliki kekayaan alam, keindahan alam, seni, budaya dan adat istiadat yang sampai saat ini pariwisata masih menjadi andalan bagi pulau bali. Kebudayaan Bali pada hakikatnya dilandasi oleh nilai-nilai yang bersumber pada ajaran agama Hindu. [1] Masyarakat Bali mengakui adanya perbedaaan (rwa bhineda), yang sering ditentukan oleh faktor ruang (desa), waktu (kala) dan kondisi yang sebenarnya di lapangan (patra). Konsep desa, kala, dan patra menyebabkan kebudayaan Bali bersifat fleksibel dan selektif dalam menerima dan mengadopsi pengaruh kebudayaan budaya lain. Bali Aga dan Suku Bali Majapahit merupakan salah satu suku bangsa yang terdapat di pulau bali. Suku Bali Aga merupakan salah satu suku bangsa bali yang menganggap sebagai penduduk bali yang asli sedangkan Suku Bali Majapahit merupakan penduduk pendatang dari Jawa keturunan dari kerajaan Majapahit Hindu. Dengan memiliki budaya yang khas yang di landasi dengan suatu agama ajaran agama Hindu memiliki tujuan hidup untuk mencapai keseimbangan dan kedamaian hidup lahir dan batin. Tujuan tersebut dapat dicapai salah satunya dengan melakukan pemujaan kepada leluhur atau kawitan. Kawitan berasal dari bahasa sansekerta yaitu Wit yang artinya asal mula atau atau ikatan leluhur berdasarkan garis keturunannya. Asal mula manusia adalah Tuhan, maka sesungguhnya setiap orang punya kawitan. misalnya leluhur pernah menjadi raja, maka keturunannya akan memakai nama kawitannya, begitu pula dengan kedudukan yang lainnya. Hal ini bertujuan untuk mengingatkan kita, bahwa kawitan bertujuan untuk mengingatkan seseorang dengan asal-usul leluhurnya dengan tetap berada pada garis keturunannya. Sehingga bisa dijadikan pedoman dan panutan kedalam hidup. Salah satunya kawitan Nararya Dalem
Benculuk Tegeh Kori yang ada di Bali dari sekian kawitan yang ada di bali.

Konsep kawitan sebenarnya dibentuk dengan tujuan untuk mempererat hubungan antar keluarga. Namun masih banyak seseorang belum mengetahui kawitanya sendiri. Secara keyakinan hal ini menyebabkan kesakitan, perselihihan antara keluarga dan sebagainya. Adapun faktor yang menyebabkan hal tersebut dapat terjadi diantara lain yaitu, kurangnya babad yang memuat dengan jelas terkait dengan kawitan yang ada di Bali. Babad yang ada pun biasanya masih dalam bentuk lontar dan menggunakan Bahasa Sansekerta yang sulit dipahami oleh masyarakat umum. Faktor lain tidak tersusunya silsilah keluarga kawitanya dengan baik, sehingga masyarakat sulit mendapat informasi yang jelas mengenai silsilah keturunan keluarganya. Disamping itu faktor perpindahan penduduk membuat semakin renggangnya hubungan antar keluarga, sehingga lama kelamaan membuat orang lupa kepada kawitanya. Generasi muda yang menjadi pewaris untuk meneruskan garis keturunan kawitanya pun kurang berminat dalam mempelajari sejarah silsilah dari kawitanya.

Pemanfaatan teknologi sudah mulai digunakan untuk mengatasi semua masalah tersebut. Salah satunya dengan menyebar informasi di Internet. Internet sebagai salah satu media informasi yang banyak diminati oleh masyarakat. Dengan adanya internet arus informasi yang cepat dapat diperoleh dengan mengakses jutaan halaman web secara mudah. Web kini telah berkembang menjadi semantic web. Web semantik merupakan web yang mempunyai knowledge base tertentu sehingga bisa dikatakan web semantik mempunyai sifat lebih pintar dari web sebelumnya. Adapaun sebuah penelitian terkait yang sudah ada antara lain penelitian yang dilakukan oleh Eka Puji Agustini (2014) yang berjudul "Perancangan Ontologi Sebagai Meta Data Aplikasi Berbasis Web Semantik. Penelitian 
selanjutnya yang dilakukan oleh Ferdila \& Mustikasar (2014) yang membuat penelitian mengenai" Aplikasi Web Semantik untuk Pencarian Materi Perkuliahan". Penelitian yang dilakukan oleh Lasmedi Afuan \& Azhari (2016) yang membuat penelitian mengenai "Penerapan Semantik Web pada Ontologi Learning Resource Repositori" penelitian yang dilakukan oleh Taufik Tirkaamiasa \& Wendi Usino (2015) yang membuat penelitian mengenai "Sistem Pakar pembagian waris menggunakan Metode Forward dan Backward Chaining".

Dari adanya permasalah dan penelitian yang sudah pernah dilakukan maka dikembangkan web semantik silsilah keluarga kawitan Nararya Dalem Benculuk Tegeh Kori.

\section{KAJIAN TEORI}

A. Sejarah Kawitan Nararya Dalem Benculuk Tegeh Kori

Berawal dari penyerangan mahapatih Gajah Mada disertai para Arya ke pulau bali dengan keberhasilan kemengangan Gajah Mada. Dan pada saat itu di duduki Sri Kresna Kepakisan sebagai Raja Dalem Bali asal keturunan Brahmana. [2]

Dimulai Dari Sebuah Fitnah kepada Arya Kenceng yang pada saat itu memiliki jabatan tertingi dalam pemerintahan Sri Kresna Kepakisan ( Sri Aji Dalem ) dan di pecat turun menjadi abdi yang terendah,. Pada saat itu Sri Aji Dalem Mempunyai beberapa putra kecil dan salah satu sangat dekat dengan Arya Kenceng. Dengan kehendak tuhan putra raja di berikan kepada Arya Kenceng. Diberilah nama seorang putra raja itu dengan nama Arya Tegeh kori. Tumbuh dewasa Kehidupan seharinya bersama saudara angkatnya Sri Arya Ngurah Tabanan dan sangat akbar keakraban mereka berdua terpecah dan terjadi sebuah perselisihan yang berpangkal dari sebuah kesalahpahaman dan kecemburuan desa Tonja di daerah badung Pada saat itu desa Tonja tidak memiliki raja, Arya Tegeh Kori datang tepat saat ada upacara di desa itu dengan kegagahan dan kewibaannya, dengan mengertahui beliau merupakan keturunan dari Raja dalem beliau diangakat menjadi sebuah raja dengan Nama Arya Benculuk Tegeh Kori. Dari inilah yang mengawali perjalanan sejarah dari kawitan Nararya Dalem Benculuk.

\section{B. Web Semantik (Web 3.0)}

Web Semantik atau Web 3.0 adalah generasi ketiga dari layanan internet berbasis web. Konsep Web 3.0 pertama kali diperkenalkan Tim Berners-Lee, merupakan sebuah sarana bagi mesin untuk membaca halaman - halaman web. Hal ini berarti bahwa mesin memiliki kemampuan membaca yang sama dengan manusia dalam membaca web.

Web semantik merupakan visi masa depan web, dan informasi diberi arti eksplisit, sehingga lebih mudah diproses oleh mesin secara otomatis dan lebih mudah menyatukan informasi yang tersedia di web. Web semantik adalah perluasan dari web yang mendukung database dalam bentuk yang dapat dibaca oleh mesin [3]

Web semantik tidak berdiri sendiri, terdiri dari berbagai macam komponenkomponen yang saling berhubungan satu sama lainnya adalah sebagai berikut.

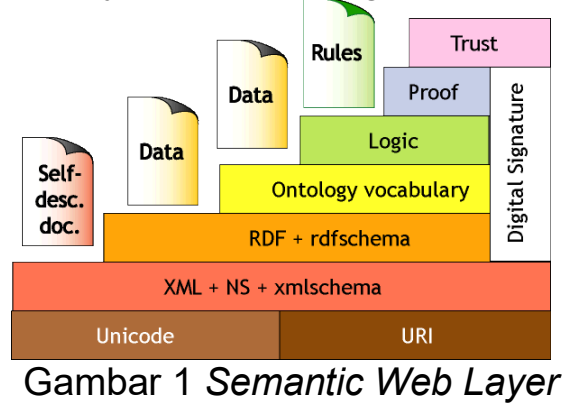

(Sumber : World Wide Web Consortium (W3C))

Lapisan - lapisan pada web semantik layer diatas memiliki fungsi yang mendeskripsikan teknologi web yang dipakai untuk membangun web semantik, dimana tiap lapisan memiliki fungsi masingmasing yaitu :.

XML, merupakan bahasa framework yang dapat digunakan bersama bahasa pemrograman lain seperti PHP, Java, Ruby, 
dan lainnya. Digunakan untuk menyimpan serta pertukaran data pada web.

XML schema, digunakan untuk mendifinisikan struktur bahasa XML tertentu.

RDF (Resource Description Framework), sebuah bahasa yang memiliki fleksibilitas dalam mendeskripsikan informasi dan metadata.. RDF schema, suatu framework yang menyediakan kosakata dasar bagi RDF yang digunakan dalam aplikasi.

Ontology, merupakan kosakata yang terdiri dari komposisi dari statementstatement yang mendefinisikan suatu konsep, hubungan dan batasan dari suatu area spesifik dalam lingkup ilmu pengetahuan. Ontology dimodelkan dengan menggunakan Ontology Web Language (OWL), yang merupakan turunan dari RFDS, dimana lebih ekspresif dalam mendefinisikan relasi dan kardinalitas dari setiap class.

Logic and Proof, penalaran logis untuk membangun konsistensi dan kebenaran suatu kumpulan data dan untuk menyimpulkan kesimpulan yang tidak dinyatakan secara eksplisit. Sedangkan untuk pembuktiannya dengan menjelaskan proses dari penalaran logis.

\section{Resource Description Framework (RDF) dan RDF Schema}

Resource Description Framework (RDF) merupakan suatu kerangka kerja umum untuk bagaimana menggambarkan setiap sumber daya Internet seperti situs web dan isinya yang sering disebut sebagai metadata. RDF Resource segala sesuatu yang berisi Uniform Resource Identifiers (URI) [5].

RDF Schema (RDFS) merupakan sebuah set standard sederhana dari sumber RDF yang memungkinkan untuk membuat vokabulari RDF sendiri. Model dari RDFS memiliki kemiripan dengan yang digunakan oleh object oriented, yaitu dengan memiliki class, relation, property dan instance. Class adalah kumpulan dari objek yang memiliki kesamaan karakter.
Relation adalah sifat hubungan antar kelas. Property adalah karakter dari sebuah kelas. Instances adalah sebuah objek yang sesungguhnya. 'arti' kata menerangkan dalam RDF atau RDFS tergantung oleh beberapa faktor, termasuk peraturan sosial, bahasa natural atau penghubung ke dokumen lain. Banyak diantara arti-arti tersebut tidak dapat diakses oleh mesin.

\section{Forward Chaining \& Backward Chaining}

Algoritma Forward Chaining merupakan metode pencarian yang memulai proses pencarian dari sekumpulan data atau fakta, dari fakta-fakta tersebut dicari suatu kesimpulan yang menjadi solusi dari permasalahan yang dihadapi.Pencarian atau teknik pelacakan ke depan yang dimulai dengan informasi yang ada dan penggabungan rule untuk menghasilkan suatu kesimpulan atau tujuan. Pelacakan maju ini sangat baik jika bekerja dengan permasalahan yang dimulai dengan rekaman informasi awal dan ingin dicapai penyelesaian akhir, karena seluruh proses akan dikerjakan secara berurutan maju. [6]

Sedangkan Backward Chaining merupakan metode pencarian yang arahnya kebalikan dari Forward Chaining. Proses pencarian dimulai dari tujuan, yaitu kesimpulan yang menjadi solusi dari permasalahan yang dihadapi.

Kasus Algoritma Forward Chaining dan Backward Chaining Misal diketahui dengan aturan-aturan rule dibawah sebagai berikut:

R-1 : IF suku bunga turun THEN harga obligasi naik.

R-2 : IF suku bunga naik THEN harga obligasi turun.

R-3 : IF suku bunga tidak berubah THEN harga obligasi tidak berubah.

R-4 : IF nilai dolar naik THEN suku bunga turun.

R-5 : IF nilai dolar turun THEN suku bunga naik. 
R-6 : IF harga obligasi turun THEN beli obligasi.

diketahui bahwa nilai dolar turun, maka untuk memutuskan apakah akan membeli obligasi atau tidak, dapat ditunjukkan sebagai berikut :

Forward Chaining (Pencarian ke depan/Maju). Dari fakta nilai dolar turun, berdasarkan R-5 diperoleh bahwa suku bunga naik, dari R-2 diperoleh suku bunga naik menyebabkan harga obligasi turun, kemudian dengan R-6 jika harga obligasi turun, maka beli obligasi. Jadi kesimpulan beli obligasi.

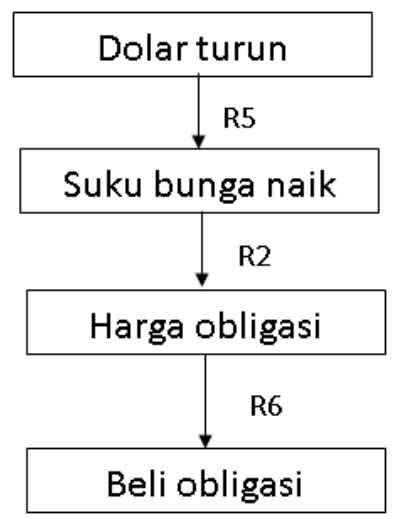

Gambar 2 Pencarian dengan Forward Chaining

Backward Chaining (Pencarian kebelakang/Mundur). Berangkat dari membeli obligasi, dengan R-6 diperoleh anteseden harga obligasi turun. Dari R-2 dapat dibuktikan bahwa harga obligasi turun bernilai benar jika suku bunga naik bernilai benar. Dari R-5, suku bunga naik memang bernilai benar karena diketahui fakta bahwa nilai dolar turun.

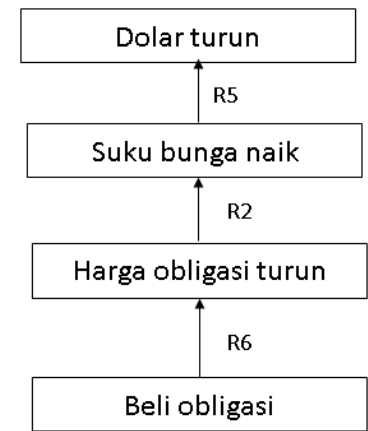

Gambar 3 Pencarian dengan backward chaining

Metode Forward Chaining Kelebihan dan Kekurangan

Kelebihan utama dari forward chaining yaitu metode ini akan bekerja dengan baik ketika problem bermula dari mengumpulkan/ menyatukan informasi lalu kemudian mencari kesimpulan apa yang dapat diambil dari informasi tersebut.

Kekurangan utama metode ini yaitu kemungkinan tidak adanya cara untuk mengenali dimana beberapa fakta lebih penting dari fakta lainnya.

Metode Backward Chaining Kelebihan dan Kekurangan

Kelebihn Memudahkan pencarian data dari belakang ke depan dengan aturan rule

Kekurangan dibatasi dengan "rule" atau aturan yang ditetapkan, jika tidak ada rule yang terpenuhi maka sistem belum bisa mengambil sebuah kesimpulan sebab belum tersedianya sebuah rule baru

\section{E. Laravel Framework}

Laravel framework Laravel adalah framework PHP dengan kode terbuka (open source) dengan desain MVC (Model-ViewController) yang digunakan untuk membangun aplikasi website.[6] Framework ini pertama kali dibangun oleh Taylor Otwell pada tanggal 22 Februari 2012. Laravel dirilis di bawah lisensi Massechusetts Institute of Technology, dengan sumber kode (source code) yang disediakan di Github [7] 
Laravel dikembangkan secara khusus untuk PHP 5.3 Mungkin banyak yang sudah tahu bahwa PHP 5.3 miliki cukup banyak fitur baru dalam segi bahasa, yang membuat php terasa lebih modern dan powerfull. Laravel dikembangkan secara khusus untuk PHP 5.3, jadi framework ini bisa memanfaatkan berbagai macam kelebihan yang dimiliki php versi terbaru tersebut. Tidak ada backward compatibility dengan PHP versi sebelumnya.

\section{METODE}

Metode yang digunakan dalam penelitian ini adalah metode waterfall. Metode waterfall adalah model klasik yang bersifat sistematis, berurutan dalam membangun software. Nama model ini sebenarnya adalah "Linear Sequential Model". Model ini sering disebut juga dengan "classic life cycle" atau metode waterfall. Model ini termasuk ke dalam model generic pada rekayasa perangkat lunak dan pertama kali diperkenalkan oleh Winston Royce sekitar tahun 1970 sehingga sering dianggap kuno, tetapi merupakan model yang paling banyak dipakai dalam Software Engineering (SE). Model ini melakukan pendekatan secara sistematis dan berurutan. Disebut dengan waterfall karena tahap demi tahap yang dilalui harus menunggu selesainya tahap sebelumnya dan berjalan berurutan.

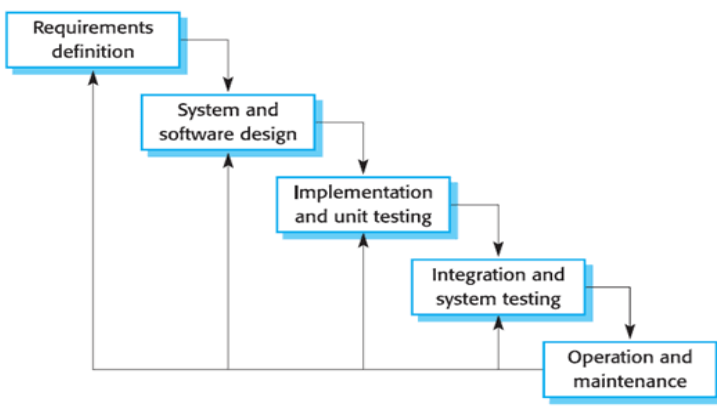

Gambar 4 Tahapan Metode Waterfall (Sumber : Galandi, 2016) [8]

Tahap requirement definition adalah tahap pertama yang dilakukan pengembang sistem untuk mencari dan mengumpulkan kebutuhan secara lengkap. Dalam pegembangan web semantik silsilah keluarga kawitan Nararya Dalem Benculuk Tegeh Kori dengan metode pencarian forward chaining dan backward chaining, hal pertama yang dilakukan adalah mengumpulkan data terkait dengan silsilah keluarga kawitan Nararya Dalem Benculuk Tegeh Kori secara lengkap dari generasi ke generasi.

Tahap system and software design adalah tahap selanjutnya yang dilakukan pengembang sistem. Pada tahap ini perancangan yang dilakukan meliputi perancangan kebutuhan perangkat lunak, perancangan model fungsional perangkat lunak, perancangan perangkat lunak, dan perancangan pengujian perangkat lunak.

Tahap implementation and unit testing adalah tahap desain sistem. Dalam pengembangan web semantik silsilah keluarga kawitan Nararya Dalem Benculuk Tegeh Kori dengan metode pencarian Forward Chaining dan Backward Chaining, tahap ini merupakan tahap implementasi (pembuatan) database dan sistem sesuai dengan rancangan yang dibuat pada tahap sebelumnnya.

Tahap integration and system testing adalah tahap dari sistem yang dibuat diujicobakan. Semua fungsi - fungsi software harus diujicobakan, agar software bebas dari error, dan hasilnya harus benarbenar sesuai dengan kebutuhan yang sudah didefinisikan. Testing dapat dilakukan dengan melakukan pengujian white box, black box dan pengujian respon pengguna..

Tahap operation and maintenance adalah tahap terakhir dari model waterfall. Pada tahap ini perangkat lunak yang sudah jadi, dijalankan serta dilakukan pemeliharaan. Pemeliharaan termasuk dalam memperbaiki kesalahan yang tidak ditemukan pada langkah sebelumnya atau ada penambahan fitur-fitur yang belum ada pada software pendukungnya dengan software lain yang mebutuhkan. 
Data yang diperoleh dalam penelitian merupakan data silsilah yang dimuat pada prasasti kawitan naraya dalem Benculuk Tegeh Kori Keluarga Penyaringan yang berada di Desa Tegal Cangkring, Kecamatan Mendoyo, Jembrana.

Pengujian kepada pengguna digunakan untuk mengetahui tanggapan dari pengguna setelah menggunakan sistem. Uji respon pengguna akan dilakukan dengan menggunakan pengujian UEQ (User Experience Questionnaire), yang merupakan sebuah metode pengukuran UX. Metode ini menggunakan kuisioner untuk mengumpulkan feedback atau umpan balik dari pengguna ketika menggunakan sebuah produk, penggunaan kuisioner ini karena kuisioner ini dinilai lebih efektif untuk menganalisis. UEQ disusun agar dapat menghasilkan sebuah hasil penelitian atau pengujian secara efektif dan tidak memakan banyak waktu. UEQ berupa kuisioner dengan 26 pertanyaan impresi atas produk yang diberikan kepada user [9].

\section{HASIL DAN PEMBAHASAN}

1. Hasil Penelitian

Tahap pertama peneliti melakukan mencari dan mengumpulkan kebutuhan secara lengkap kemudian dianalisis dan didefinisikan dari requirement analysis and definition (analisis kebutuhan dan definisi) pada model tersebut. Pada tahap ini penulis mencari informasi dan mengupulkan data serta menganalisis khususnya silsilah keluarga kawitan Nararya Dalem Benculuk Tegeh Kori. Berdasarkan hasil pengumpulan data di dapatkan silsilah kawitan Nararya Dalem Benculuk Tegeh Kori Keluarga Penyaringan, Desa Tegal Cangkring, Kecamatan Mendoyo, Jembrana. dari prasasti tersebut menjadi sumber informasi terkait dengan perjalanan leluhur.

Tahap ini merupakan tahap kedua dalam model waterfall yaitu masuk kedalam bagian dari System and Software Design (sistem dan desain perangkat lunak). Tahap ini memaparkan tahapan awal dari perangkat lunak yang akan dikembangkan, yaitu meliputi kebutuhan perangkat lunak, tujuan pengembangan perangkat lunak, masukan dan keluaran perangkat lunak, dan model fungsional perangkat lunak. Model fungsional perangkat lunak adalah sebagai berikut.

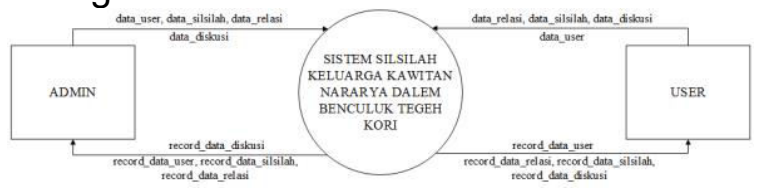

Gambar 5 Diagram Konteks

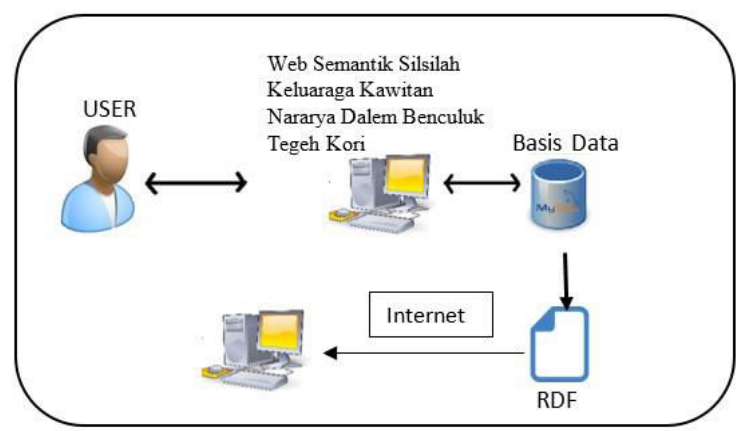

Gambar 6 Arsitektur Perangkat Lunak

User yang telah terdaftar di dalam sistem akan dapat menambahkan anggota keluarganya ke sistem. Data yang ditambahkan akan disimpan ke dalam database sistem. Database tersebut kemudian akan di ubah kedalam bentuk RDF.

Tahapan Implementasi, ini,merupakan tampilan yang telah dibuat pada tahapan sebelumnya diimplementasikan menjadi sebuah perangkat lunak yang telah berfungsi dan dapat digunakan oleh pengguna sesuai dengan fungsi-fungsi yang telah ditetapkan sebelumnya. Adapun implementasi tampilan antarmuka perangkat lunak Web Semantik Silsilah Keluarga Kawitan Nararya Dalem Benculuk Tegeh Kori dengan Metode Pencarian Forward Chaining dan Backward Chaining seperti berikut. 

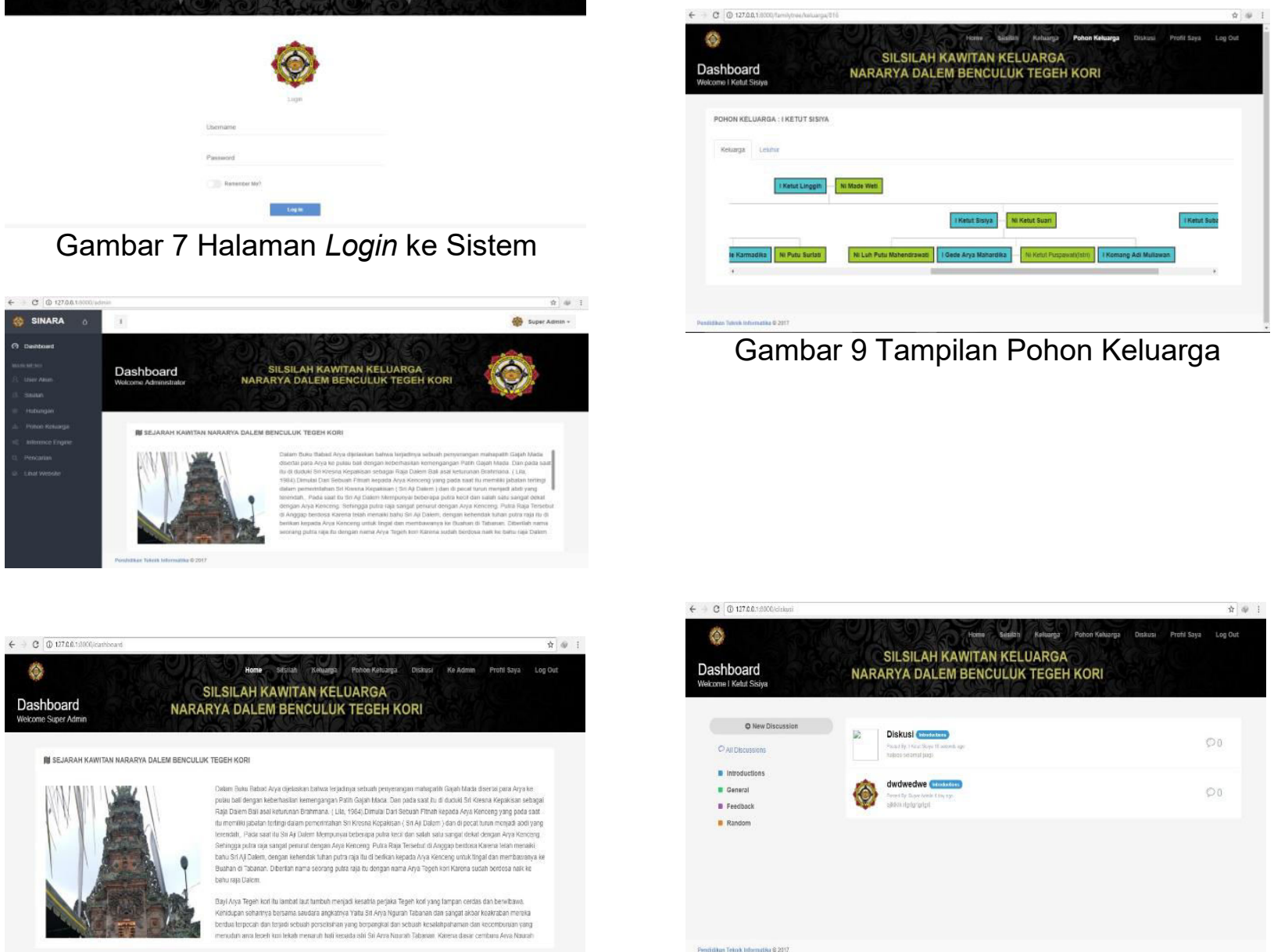

Gambar 10 Tampilan Dashboard User

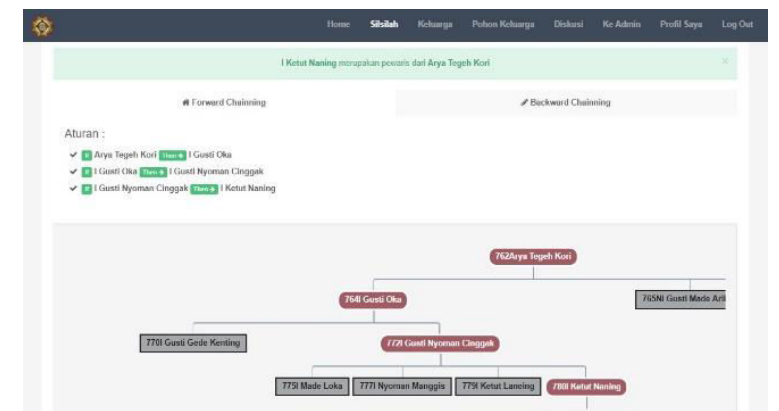

Gambar 11 Tampilan Hasil Pencarian Forward Chaining \& Backward Chaining

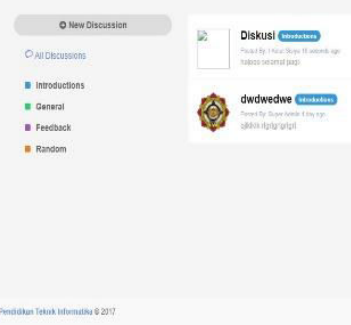

Gambar 12 Tampilan Forum Diskusi

Tahap Pengujian, pengujian respon pengguna ini dilakukan dengan melibatkan pengguna secara langsung menggunakan sistem. Adapun pengguna yang dilibatkan keluarga kawitan Nararya Dalem benculuk Tegeh Kori sebanyak 10 orang. Hasil dari pengujian adalah sebagai berikut. 
Tabel 1 Hasil Analisis Data dengan UEQ Data Analysis Tool

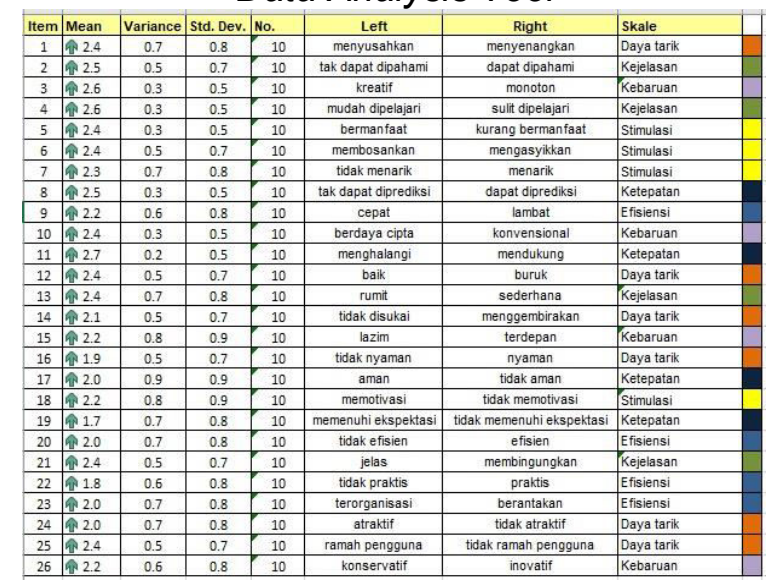

Dari hasil analisis yang dilakukan dengan mengubah 26 item penilaian pada angket UEQ menjadi 6 skala yaitu daya tarik, kejelasan, efisiensi, ketepatan, stimulasi, dan kebaruan sistem web semantik silsilah keluarga kawitan Nararya Dalem Benculuk Tegeh Kori mencapai hasil sebagai berikut.

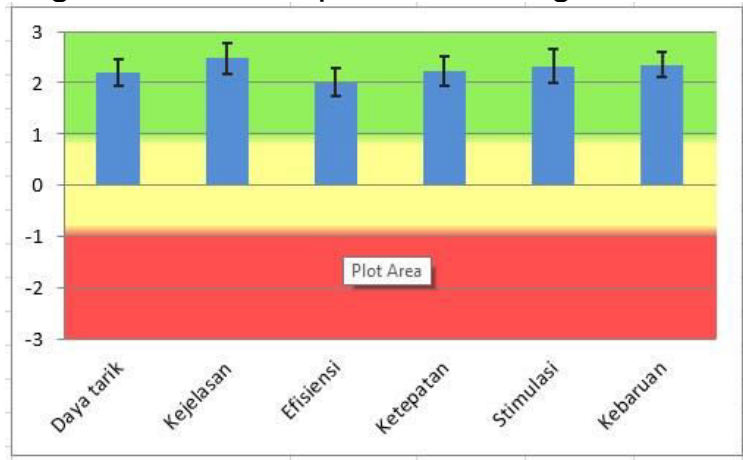

Gambar 12 Grafik Hasil Pengolahan Data Responden

Adapun nilai rata-rata impression setiap kelompok pertanyaan adalah Daya Tarik: 2.200; Kejelasan: 2.475; Efisiensi: 2.000; Ketepatan: 2.225; Stimulasi: 2.325; Kebaruan: 2.350. Sehingga dapat disimpulkan sistem Web Semantik Silsilah Keluarga Kawitan Nararya Dalem Benculuk Tegeh Kori dengan predikat sangat baik.

Tahap terakhir merupakan mengoperasikan dan memelihara sistem yang telah dikembangkan. Tahap ini adalah bagian dimana untuk melakukan kegiatan rutin seperti system maintenance, backup data dan system modification.

\section{PEMBAHASAN}

Web Semantik (Web 3.0) sebuah sarana bagi mesin untuk membaca halaman-halaman Web. Hal ini berarti bahwa mesin akan memiliki kemampuan membaca web sama seperti yang manusia dapat lakukan. Web semantik tersusun dari berbagai layer. Lapisan-lapisan yang mendeskripsikan teknologi web yang dipakai untuk membangun semantik web seperti XML, XML schema, RDF (Resource Description Framework), RDF schema, Ontology, OWL dan Logic and Proof. Pengembangan web semantik silsilah keluarga Dalem Benculuk Tegeh Kori dengan metode pencarian Forward dan Backward Chaining hanya sampai tahap pembuatan RDF (Resource Description Framework). RDF kerangka kerja untuk mendeskripsikan resource dari informasi pada web. RDF dirancang untuk memberikan cara yang umum untuk menggambarkan suatu informasi sehingga dapat dibaca dan dipahami oleh aplikasi komputer. Untuk membuat RDF digunakan bahasa XML dimana dalam pembuatan RDF disebut dengan RDF/XML. RDF mengidentifikasi hal - hal yang menggunakan pengenal web (URI) dan mendeskripsikan sebuah Resource dengan Property dan Property Value. Kombinasi dari Resource, Property, dan Property Value membentuk suatu pernyataan dimana dalam suatu pernyataan ketiga hal tersebut dikenal dengan Subjek, Predikat, dan Objek. Pada implementasi penyelesaia RDF data yang sebelumnya masih database relasi kemudian di generate ke RDF sebagai berikut.

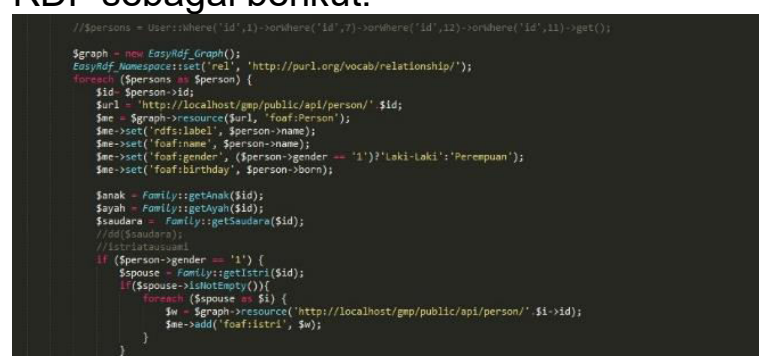

Gambar 13 source code pembuatan RDF 
Hasil Data RDF sudah sesuai dengan rancangan dan data RDF sebagai berikut.

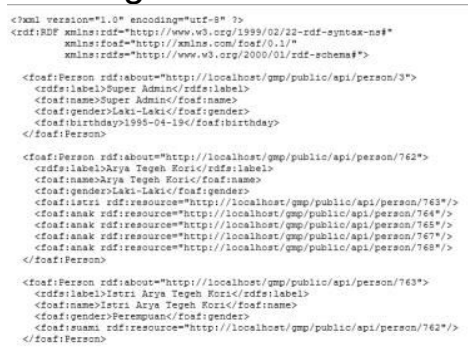

Gambar 14 : Hasil Data RDF

tervalidasi Gambar 4.44 RDF Validasi.

Selain itu juga terdapat beberapa perubahan yang dilakukan, seperti menambah atau mengurangi field maupun membuat tabel baru sesuai dengan kebutuhan saat proses pengembangan sistem dilakukan. Setelah proses desain tersebut selesai, maka dilanjutkan ke tahap pengembangan atau pembuatan sistem sesuai kebutuhan fungsional dan desain rancangan system yang telah dibuat. Sistem dirancang menggunakan bahasa pemrograman PHP dalam hal ini yaitu framework laravel dan dijalankan dalam sistem operasi windows 10 dengan database MySQL dan web server Apache. Pada pengembangan aplikasi ini terdapat beberapa perangkat lunak yang dibutuhkan yaitu Sublime Text 3 sebagai text editor, untuk membuat kode program baik untuk tampilan maupun function proses di dalam sistem. Selanjutnya untuk server (localhost) peneliti menggunakan aplikasi XAMPP dan untuk web browser yang digunakan, peneliti menggunakan Google Chrome untuk mencoba aplikasi ketika pengembangan.

Pada sistem ini pengguna harus terdaftar terlebih dahulu ke dalam sistem agar dapat masuk ke dalam sistem untuk mengetahui lebih jelas terkait sejarah, silsilah keluarga kawitan Nararya Dalem Benculuk Tegeh Kori. Sistem ini bertujuan untuk membantu masyarakat khusunya yang memiliki kawitan Nararya Dalem Benculuk Tegeh Kori dalam menampilkan informasi silsilah keluarga dari kawitan tersebut. Selain itu pada sistem ini pengguna juga akan dipermudah dalam berinteraksi dengan sesama anggota kawitan Dalem Benculuk Tegeh Kori karena adanya fitur forum diskusi pada aplikasi ini.

Pengujian aplikasi dilakukan untuk mengetahui kesalahan pada pengkodean dan fungsional dari sistem. Pengujian yang pertama dilakukan adalah pengujian white box. Pengujian white box bertujuan untuk menguji aplikasi dengan cara melihat modul untuk dapat menganalisa kode dari program yang di buat ada yang salah atau tidak. Berdasarkan pengujian white box, aplikasi sudah benar dan output sudah sesuai dengan algoritmanya. Kedua adalah pengujian black box yang bertujuan untuk menguji fungsionalitas form dalam sistem. Berdasarkan pengujian black box, fungsionalitas dari form sistem sudah sesuai dengan kebutuhan fungsional. Pengujian berikutnya adalah pengujian respon pengguna dengan pengujian UEQ dapat dikatakan berhasil.

\section{SIMPULAN}

Sistem Web Silsilah Keluarga Kawitan Nararya Dalem Benculuk Tegeh Kori dikembangkan dengan tujuan untuk memberi informasi terkait kawitan Nararya Dalem Benculuk Tegeh Kori dengan menggunakan data yang sesuai berdasarkan prasasti Arya Tegeh Kori keluarga Penyaringan, serta sumbersumber lain yang ada..

Respon pengguna yaitu masyarakat yang menjadi keluarga dari kawitan Nararya Dalem Benculuk Tegeh Kori terhadap aplikasi Web Semantik Silsilah Keluarga Kawitan Nararya Dalem Benculuk Tegeh Kori dengan Metode Pencarian Forward Chaining dan Backward Chaining mendapat respon yang baik, mereka sangat tertarik dan antusias untuk mencoba sistem. Dari hasi uji di lapangan terhadap 10 masyarakat Keluarga Kawitan Nararya Dalem Benculuk Tegeh Kori didapatkan hasil bahwa sistem masuk kategori sangat baik. 


\section{REFERENSI}

[1] Nirwana. Nirwana dan Cara Pencapaianya dalam Agama Hindu.2015.100.

[2] Lila. Babad Arya Tegeh Kori.1984.

[3] Koivunen, R., Eric, M. W3C Semantic Web Activity.2001.w3.org.

[4] Nurnawati,E.K. Representasi Database Berbasis Ontlogi dengan Resource Description Framework (RDF).

[5] Danny, A.,Pegertian Forward Chaining dan backward Chaining.2012.

[6] Aminudin.Cara Efektif Belajar Framework Laravel. Yogyakarta:CV. Lokomedia:2015.

[7] Khasanah, A.K. Pengembangan dan Analisis Kualitas Berdasarkan ISO 9126
Aplikasi Pendeteksi gaya Belajar Model Vak (Visual, Auditorial, Kinestesik).2015

[8] Galandi, F. Metode Waterfall : Definisi, Tahapan, Kelebihan dan Kekurangan. Retrieved from pengetahuandanteknologi.com: http://www.pengetahuandanteknologi.co $\mathrm{m} / 2016 / 09 /$ metode-waterfall-definisitahapan.html.2014

[9] Lestari,P.N., Santosa,P.I., Frediana,R. Pengukuran Pengalaman Pengguna dalam Menggunakan Sistem Informasi Akademik. Seminar Nasional Teknologi Informasi dan Komunikasi (SENTIKA) 2016: 136-143. 